\title{
Viscosity of Sumbawa Honey Based on Faxen Correction Factor: Consumer Protection Efforts against Fraud
}

\author{
Moh. Irma Sukarelawan ${ }^{1}$, Yudhiakto Pramudya ${ }^{2}$, Siti Anisatur Rofiqah ${ }^{3}$, Endra Putra \\ Raharja ${ }^{4}$ \\ Universitas Ahmad Dahlan, Indonesia ${ }^{1,2}$, Universitas Negeri Yogyakarta, Indonesia ${ }^{1}$, STKIP \\ Nurul Huda, Indonesia ${ }^{3}$, Universitas Pendidikan Muhammadiyah Sorong, Indonesia ${ }^{4}$ \\ moh.sukarelawan@mpfis.uad.ac.id ${ }^{1}$, yudhiakto.pramudya@pfis.uad.ac.id ${ }^{2}$, \\ anis@stkipnurulhuda.ac.id ${ }^{3}$, endra@unimudasorong.ac.id ${ }^{4}$
}

Received: September $25^{\text {th }}, 2020$. Revised: November $10^{\text {th }}, 2020$. Accepted: November $17^{\text {th }}, 2020$

\begin{abstract}
Keywords :
Apis Dorsata; Consumer

Protection; Faxen Correction

Factor; Sumbawa Honey;

Viscosity

ABSTRACT

This study is aimed at determining the viscosity of Sumbawa honey. The sample used was produced by the Apis Dorsata species of honeybees, having three different types of concentrations: $10 \%, 20 \%$ and $30 \%$, respectively. The test sample solution was at a temperature of $23.3 \pm 0.5^{\circ} \mathrm{C}$. The viscosity value was determined using the corrected vertical spherical oscillation method. The results of this study identified a tendency for increased viscosity to the concentration of honey solution, which has been determined by extrapolating the equation of the linear regression. The relationship of concentration to true viscosity satisfies the equation $y=0.0199 x+0.0160$. Furthermore, the Sumbawa honey viscosity was 2.006 Pa.s.
\end{abstract}

\section{INTRODUCTION}

Indonesia is one of the countries with diversified flora and fauna [1]. Bee produces honey with various benefits, and as a natural biological product [2] [3] [4], several researches have confirmed that it is beneficial in the health and food industries [4] [5] [6] [7] [8] [9] [10] [11] since the existence of ancient cultures [11] [12] [13]. Therefore, honey has its own place in the world of traditional medicine [14].

Consumption of honey is generally in pure form. However, various forms have been widely marketed with increased knowledge and development. Pure honey in the market comes from managed beekeeping, honey hunting from wild living and Bee maintaining [1] [13] [15]. Awareness of its myriad benefits, the market demand in Indonesia is increasing. National honey production capacity is able to fulfill $66 \%$ of the national requirements [16] [17].

Some physical parameters have been used as standard criteria in determining honey quality. Some of which include: water content [18] [19], viscosity [15] [20] [21] [22], optical rotation [23] [24] [25], electrical conductivity [19] [26], density [27], colour intensity [12] [28] [29], refractive index [30], osmotic pressure [31] [32], crystallization [33] [34], and hygroscopicity, glass transition temperature, and surface stickiness [29]. The physical properties of honey, such as viscosity, has been widely reported 
from different countries [19] [29] [35] [36] [37]. Viscosity determines how honey is received at the consumer level [30], processed, handled and stored [22] [30] [38].

The viscosity of various types of honey from various countries has been widely reported [39]. However, there are limited publications from Indonesia, including the Sumbawa Regency. Reports on the viscosity of forest honey are limited to those from Kalimantan, West Sumatra, South Sulawesi, and Pekanbaru [15] [21]. As already established, Sumbawa is known for honey production nationwide [13]. Therefore, this study intends to fill the gap that occurs by determining the viscosity of Sumbawa honey as an effort to protect consumers from fraud efforts [22].

\section{Sumbawa Honey}

Honey is a natural product in the form of thick liquid with a sweet, textured flavor [3] [12] [19] [40]. Some highly productive honey bee species are: Apis dorsata, Apis mellifera, Apis cerana [22] [35]. However, it comes from plant nectar, as a natural biological product [3].

According to the Lewoyehu \& Amar report [40], honey contains more than 300 chemicals, and its variation in compositions depends on many factors such as the plants the bees eat, geography, intensity of nectar flow, climatic conditions and honey handling, and packaging and storage activities [12] [41]. The main contents include carbohydrates, water and other small components [42]. Generally, fructose monosaccharaides are more dominant than glucose. However, some types have a higher glucose monosaccharide ratio than fructose [30]. In addition, sucrose is another constituent of carbohydrate; its thick nature has caused honey to have viscosity parameters. Sumbawa forest honey is produced by bees from the Apis dorsata species [13]. This type comes from poaching by local people in the forest, since it cannot be managed [1].

\section{Viscosity}

Viscosity is a quantity expressing the magnitude of internal friction in a fluid, as measured by the force per unit area resisting uniform flow [43]. In liquids, this friction is caused by inter-molecular attraction [27]. Various methods have been used to measure viscosity including: the ball falling, the fluid flow in capillary tubes, Diffusion-Ordered NMR Spectroscopy, the cone-and-plates, and the oscillation method [44] [45] [46] [47] [48]. The oscillation method utilizes ball motion with low speed in fluid. This situation gives rise to viscous friction and turbulent forces, which can be ignored due to low speed of the ball [49].

\section{METHOD}

The spherical oscillation equation in fluid satisfies equation (1) [49].

$$
F_{s}=-6 \pi \eta r\left(1+\frac{r}{\delta}\right) v
$$

Where $v, r, \eta$ and $\delta$ are velocity, radius, viscosity and depth of penetration, respectively. Based on equation (1), the damping coefficient $b$ is expressed by equation (2)

$$
b=6 \pi \eta r\left(1+\frac{r}{\delta}\right)
$$

Vertical spherical oscillations meet equation (3) and the solution is expressed by equation (4). When the maximum displacement $(t=n T)$, equation (4) satisfies equation (5).

$$
\ddot{y}+\frac{b}{m} \dot{y}+\omega_{0}^{2} y=0
$$


Viscosity of Sumbawa Honey Based on Faxen Correction Factor: Consumer Protection Efforts against Fraud Moh. Irma Sukarelawan, Yudhiakto Pramudya, Siti Anisatur Rofiqah, Endra Putra Raharja

$$
\begin{gathered}
y(t)=A_{0} e^{-\frac{b t}{2 m}} \cos (\omega t+\varphi) \\
\ln A=-\frac{b T}{2 m} n+\ln A_{0}
\end{gathered}
$$

Equation (5) is a form of linear equation that has a slope $a_{1}=-\frac{b T}{2 m}$ and intercept $a_{0}=\ln A_{0}$. The $A_{0}, A, \varphi$ are the initial displacement, the displacement at each time, and the initial angular frequency, respectively. Whereas $n$ and $T$ are the count vibration and the average period of one vibration. Based on equation (1) and equation (5), the viscosity of the measured fluid ( $\eta_{\text {measured }}$ ) is expressed by equation (6) [47].

$$
\eta_{\text {measured }}=\frac{2 m a_{1}}{3 \pi d T\left(1+\frac{d}{2 \delta}\right)}
$$

Empirically, the oscillation of the sphere in the tube affects the tube wall, and the measured viscosity of the fluid needs to be corrected using the Faxen correction factor [50]. The true viscosity $\left(\eta_{\text {true }}\right)$ satisfies equation (7).

$$
\eta_{\text {true }}=\eta\left(1-2.104\left(\frac{d}{D}\right)+2.09\left(\frac{d}{D}\right)^{3}-0.95\left(\frac{d}{D}\right)^{5}\right)
$$

Where $D$ is the diameter of the tube. Measured and true viscosity errors in fluids are obtained from equation (8) and equation (9) [52].

$$
\begin{gathered}
s_{\eta_{\text {measured }}}=\left\{\left(\frac{\partial \eta_{\text {measured }}}{\partial m} s_{m}\right)^{2}+\left(\frac{\partial \eta_{\text {measured }}}{\partial a_{1}} s_{a_{1}}\right)^{2}+\left(\frac{\partial \eta_{\text {measured }}}{\partial T} s_{T}\right)^{2}\right. \\
\left.+\left(\frac{\partial \eta_{\text {measured }}}{\partial \delta} s_{\delta}\right)^{2}+\left(\frac{\partial \eta_{\text {measured }}}{\partial d} s_{d}\right)^{2}\right\}^{1 / 2} \\
s_{\eta_{\text {true }}}=\left\{\left(\frac{\partial \eta_{\text {true }}}{\partial \eta} s_{\eta}\right)^{2}+\left(\frac{\partial \eta_{\text {true }}}{\partial d} s_{d}\right)^{2}+\left(\frac{\partial \eta_{\text {true }}}{\partial D} s_{D}\right)^{2}\right\}^{1 / 2}
\end{gathered}
$$

Where $s_{m}, s_{a_{1}}, s_{T}, s_{\delta}, s_{d}, s_{\eta}, s_{D}$ are errors for ball mass, slope, period of vibration, depth of penetration, ball diameter, viscosity, and tube diameter.

Honey samples used in this research were obtained from one of the local forest hunters in the national market of Sumbawa Regency, Nusa Tenggara Barat, Indonesia. The sample measurements were made at temperature $23.3 \pm 0.5^{\circ} \mathrm{C}$. The experimental setup tools were shown in Figure 1 . The ball mass $(m)$ is $0.15211 \pm 0.00005 \mathrm{~kg}$ and diameter $(d)$ of $0.01796 \pm 0.00001 \mathrm{~m}$. Diameter of tube $(D)$ is $0.08024 \pm$ $0.00001 \mathrm{~m}$ and depth $(h)$ is $0.13046 \pm 0.00001 \mathrm{~m}$. 


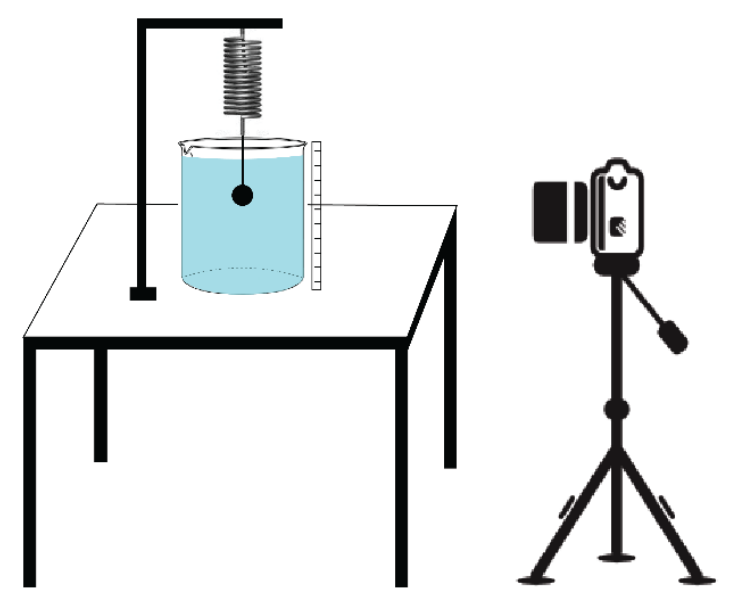

Fig 1. Setup ball oscillation experiments

After setting up the device as shown in Figure 1, the ball oscillation inside the honey was recorded using a mobile phone camera. Furthermore, the video was analyzed using video analysis software, Tracker.

The analysis technique used was linear regression. It was used to get the slope value from the graph that represented the value of the damping coefficient $b$. The measured viscosity value was determined using equation (6) for each concentration. Furthermore, viscosity was calculated using the equation (7), and was determined using extrapolation techniques.

\section{RESULTS AND DISCUSSIONS}

The experiment was done by observing the oscillation of submerged ball inside the honey. There are three honey concentration. They are 10\%, 20\% and 30\%. The concentration number is the volume ratio between honey and water. By measuring the oscillation amplitude per cycle, we are able to calculate the viscosity of the honey. The Tracker software produces the data of oscillation amplitude. The amplitude is modified into the logarithmic value to create the linear fitting. Equation 5 requires the plot of amplitude logarithmic value to the number of oscillation.

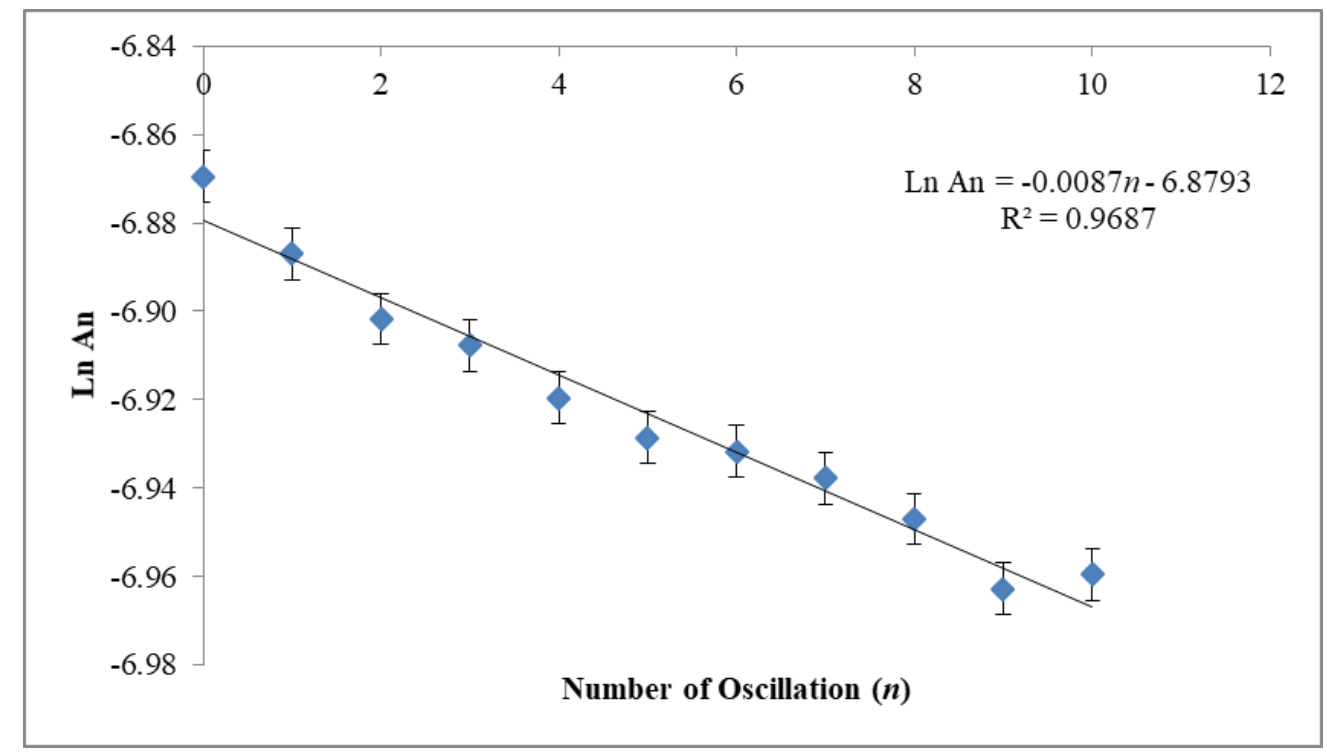

Fig 2. Relationship of amplitude logarithm to count of vibrations at concentrations $10 \%$ 
The graph of amplitude logarithmic versus number of oscillation for concentration of $10 \%$ is shown in Figure 2. By linear fitting, the slope is -0.0087 . The slope is steeper as the concentration increased. The Figure 3 shows the amplitude logarithmic versus number of oscillation for concentration of $20 \%$. The slope is -0.0092 . Finally, the slope for concentration of $30 \%$ is -0.0106 . It is shown in Figure 4.

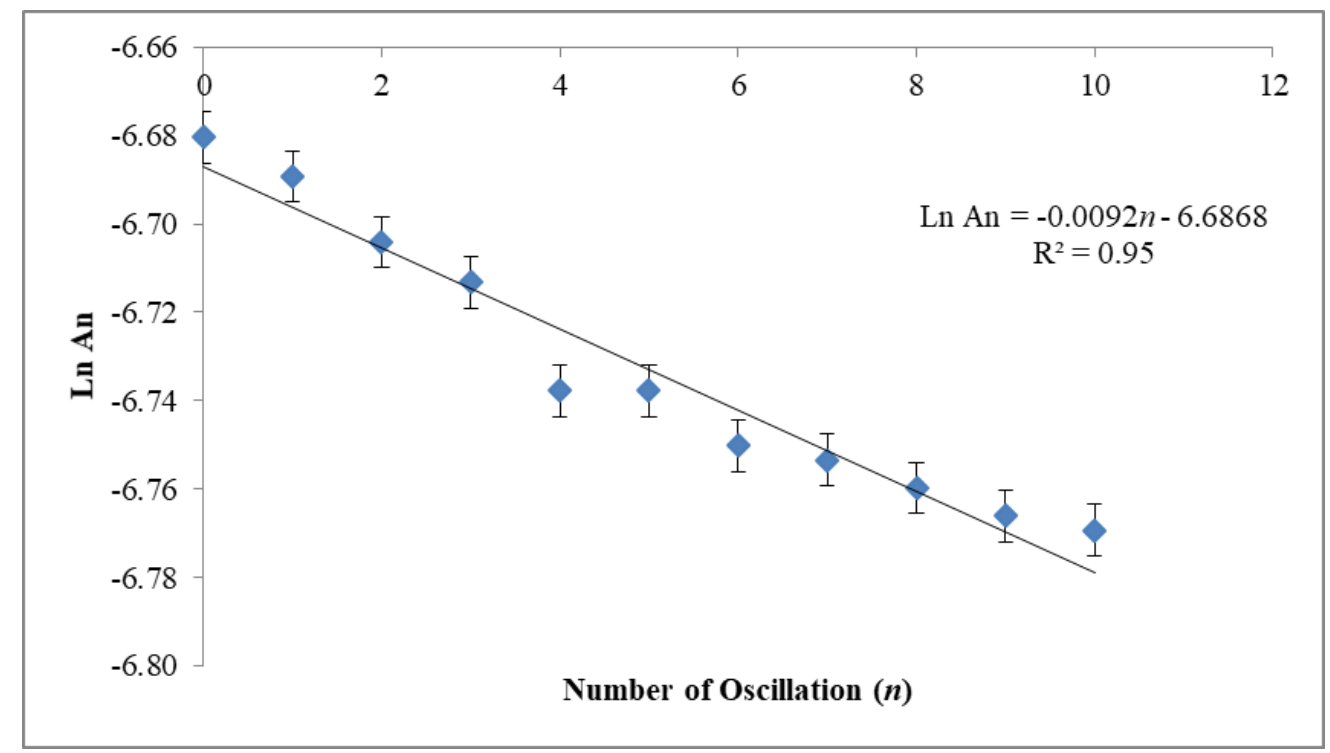

Fig 3. Relationship of amplitude logarithm to count of vibrations at concentrations $20 \%$

As we observed from the Figure 2, Figure 3, and Figure 4, the amplitude of oscillation is lower as the number of oscillation increased. This decay phenomenon is known as the damped oscillation. The damping process occurs due to the thickness of the honey. The harmonic motion is underdamped oscillation [51]. After analyzing with equation (5), the damping coefficient $b$ was obtained at each concentration. Furthermore, it was used to determine the viscosity value of honey solution based on equation (6).

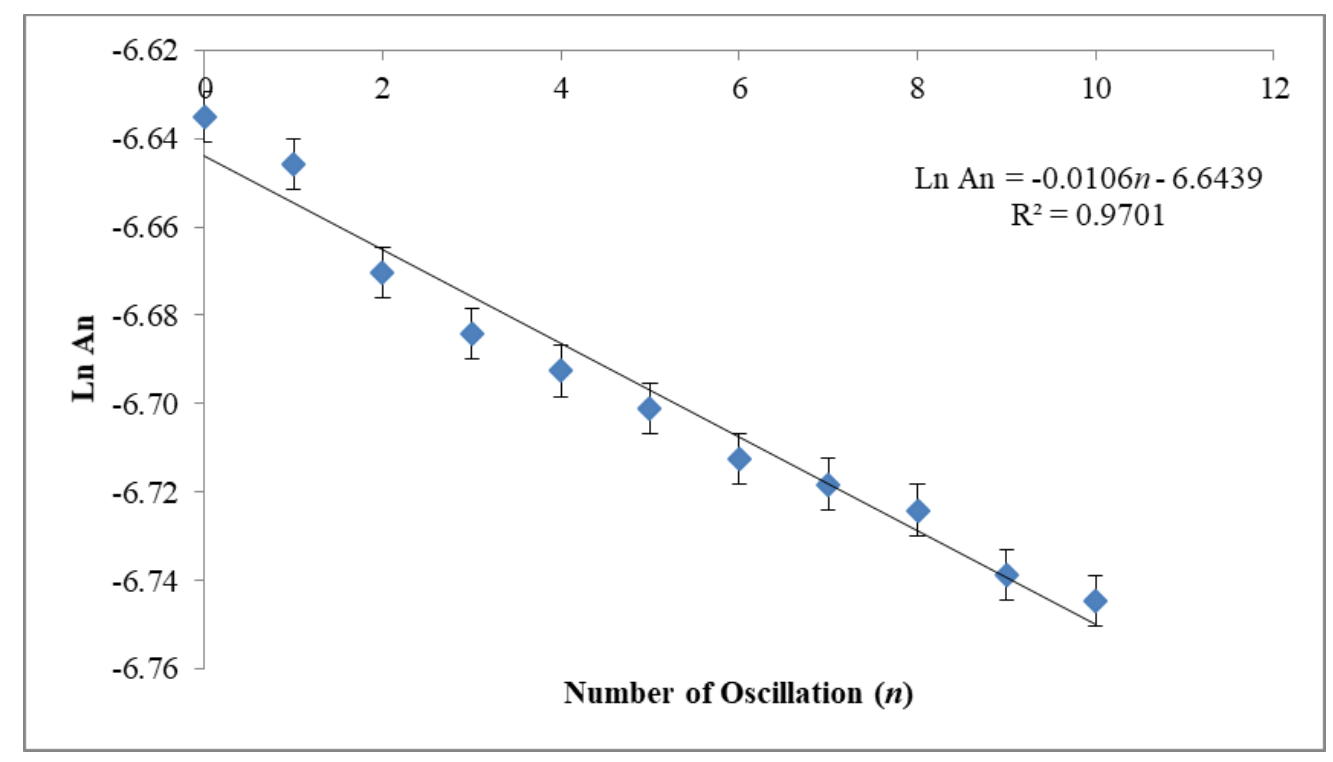

Fig 4. Relationship of amplitude logarithm to count of vibrations at concentrations $30 \%$

In addition, Faxen correction factor of 0.55 was obtained from the experimental setup. Empirically, the 
honey viscosity value, after correction of the wall effect, was obtained based on equation (7). All of these values were summarized in Table 1.

Table 1. Viscosity and damping coefficient of Sumbawa honey solution

\begin{tabular}{cccc}
\hline Concentration & $\begin{array}{c}\text { Damping Coefficient } \\
\left(\mathbf{1 0}^{-3} \mathbf{~ k g} / \mathbf{s}\right)\end{array}$ & $\begin{array}{c}\text { Measured Viscosity } \\
\left(\mathbf{1 0}^{-2} \mathbf{P a . s}\right)\end{array}$ & $\begin{array}{c}\text { True Viscosity } \\
\left(\mathbf{1 0}^{-\mathbf{2}} \mathbf{P a . s}\right)\end{array}$ \\
\hline $10 \%$ & 6.10 & $3.31 \pm 0.20$ & $1.83 \pm 0.09$ \\
$20 \%$ & 6.52 & $3.53 \pm 0.23$ & $1.95 \pm 0.13$ \\
$30 \%$ & 7.43 & $4.03 \pm 0.16$ & $2.22 \pm 0.11$ \\
\hline
\end{tabular}

Table 1 shows the damping coefficients of the solutions in range $(6.10-7.43) \times 10^{-3} \mathrm{~kg} / \mathrm{s}$. In addition, Table 1 implied that the increase in the viscosity value is directly proportional to the concentration of the Sumbawa honey solution. This phenomenon is consistent with the viscosity behavior of other types of honey reported in some previous literature [12] [30] [52]. Furthermore, a viscosity reduction of around $55 \%$ was seen after correction due to the wall effect. For example, at a concentration of $10 \%$, it is equal to $(3.31 \pm 0.20) \times 10^{-2} \mathrm{~Pa}$.s and after correction is $(1.83 \pm 0.09) \times 10^{-2} \mathrm{~Pa}$.s. Therefore, correction value is required to get an accurate viscosity as a result of wall effect. Faxen correction factor needed to be taken into account because as long as the ball experienced oscillation, the driving force to move away from the tube wall will be acquired [50].

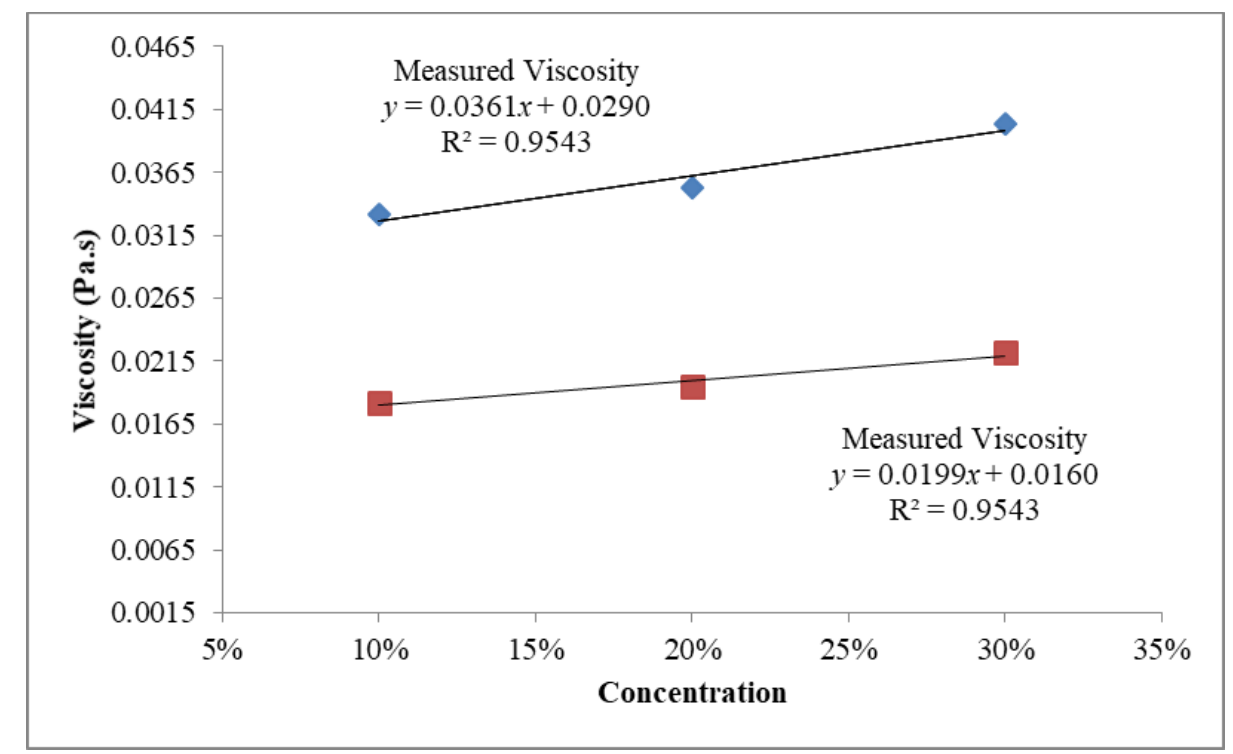

Fig 5. Relationship of viscosity to the concentration of honey solution

Figure 5 shows the correlation between viscosity and the concentration of honey solution. We can extrapolate the data in Figure 5 to determine the measured and actual viscosity for pure honey. Data extrapolation was carried out to confirm the value of the solution at concentrations of $0 \%$ and $100 \%$. Water viscosity can be confirmed using Figure 5 by substituting a solution concentration of $0 \%$. The measured water's viscosity was obtained at $2.90 \times 10^{-2} \mathrm{~Pa}$.s. The true value of water viscosity is $1.60 \times$ $10^{-2} \mathrm{~Pa}$.s with a confidence level of $95 \%$. The pure Sumbawa honey was determined by extrapolating and substituting a concentration value of $100 \%$. The measured viscosity of pure Sumbawa honey was obtained for 3.369 Pa.s and the true value is 2.006 Pa.s. The viscosity value of the sample obtained was slightly different from the results of several studies. Kek, Chin, Yusof, Tan, and Chua obtained the viscosity of Tualang and Gelam honey from similar bee species by $0.76 \mathrm{~Pa}$.s and $0.53 \mathrm{~Pa}$.s at $25{ }^{\circ} \mathrm{C}$ [22]. Furthermore, Saxena, Panicker, and Gautam obtained viscosity of seven commercial Indian honey brands ranging from 2.3 Pa.s to $16.0 \mathrm{~Pa} . \mathrm{s}$ at $25^{\circ} \mathrm{C}$ [53]. The difference was reasonable because of some differences such as the source of nectar and the temperature of the solution sources of nectar caused differences in the content of polysaccharides, having the ability to produce anti-plasticizing effects. Its high content increased the strength of sugar-sugar hydrogen bonding between the oligosaccharides. 
Viscosity of Sumbawa Honey Based on Faxen Correction Factor: Consumer Protection Efforts against Fraud Moh. Irma Sukarelawan, Yudhiakto Pramudya, Siti Anisatur Rofiqah, Endra Putra Raharja

Therefore, high polysaccharide content increased viscosity [30] [39] [42]. The difference in value was also influenced by differences in the temperature of the sample. Higher sample temperatures have high thermal movements between molecules. The movement of these molecules resulted in a decreased intermolecular and hydrodynamic forces, thus facilitating the flow [42] [53] [54], because the sample temperature in this research was lower, it was very logical to obtain a viscosity value slightly higher than some other research results.

\section{CONCLUSION AND SUGGESTION}

The determination of the viscosity value of Sumbawa honey has been carried out using the ball oscillation method with the weighted linear regression technique. The true viscosity of honey from Sumbawa is $2.006 \mathrm{~Pa}$.s calculated through extrapolation techniques. The value of viscosity obtained is not the same due to differences in the source of nectar and the temperature of the sample used. However, the results show that there is a tendency for increased viscosity to the concentration of honey solution as the findings have been documented in various previous literatures. Therefore, the finding of the viscosity value is expected to be used as a reference for one of the physical parameters of Sumbawa honey, and implications for consumer protection against the circulation of fake Sumbawa honey.

\section{REFERENCES}

[1] Gratzer, K., Susilo, F., Purnomo, D., Fiedler, S., \& Brodschneider, R. (2019). Challenges for beekeeping in Indonesia with autochthonous and introduced bees. Bee World, 96(2): 40-44.

[2] Carreck, N. L. (2018). Honey. Journal of Apicultural Research, 57(1): 1-4.

[3] Subramanian, R., Umesh Hebbar, H., \& Rastogi, N. K. (2007). Processing of honey: A review. International Journal of Food Properties, 10(1): 127-143.

[4] Musa Özcan, M., \& Al Juhaimi, F. (2015). Honey as source of natural antioxidants. Journal of Apicultural Research, 54(3): 145-154.

[5] Reybroeck, W. (2018). Residues of antibiotics and chemotherapeutics in honey. Journal of Apicultural Research, 57(1): 97-112.

[6] Otim, A. S., Kajobe, R., Abila, P. P. O., Kasangaki, P., \& Echodu, R. (2019). Important Plants for Honey Production in Four Agro Ecological Zones of Uganda. Bee World, 96(3): 81-86.

[7] Ahmed, Z. H., Tawfik, A. I., Abdel-Rahman, M. F., \& Moustafa, A. M. (2020). Nutritional Value and Physiological Effects of Some Proteinaceous Diets on Honey Bee Workers (Apis mellifera L.). Bee World, 97(1): 26-31.

[8] Beretta, G., Granata, P., Ferrero, M., Orioli, M., \& Facino, R. M. (2005). Standardization of antioxidant properties of honey by a combination of spectrophotometric/fluorimetric assays and chemometrics. Analytica Chimica Acta, 533(2): 185-191.

[9] Al-Mamary, M., Al-Meeri, A., \& Al-Habori, M. (2002). Antioxidant activities and total phenolics of different types of honey. Nutrition research, 22(9): 1041-1047.

[10] Doner, L. W. (1977). The sugars of honey-a review. Journal of the Science of Food and Agriculture, 28(5): 443-456.

[11] Bogdanov, S., Jurendic, T., Sieber, R., \& Gallmann, P. (2008). Honey for nutrition and health: a review. Journal of the American College of Nutrition, 27(6): 677-689.

[12] Eteraf-Oskouei, T., \& Najafi, M. (2013). Traditional and modern uses of natural honey in human diseases: a review. Iranian journal of basic medical sciences, 16(6): 731-742.

[13] Schouten, C., Lloyd, D., \& Lloyd, H. (2019). Beekeeping With the Asian Honey Bee (Apis cerana javana Fabr) in the Indonesian Islands of Java, Bali, Nusa Penida, and Sumbawa. Bee world, 96(2): 45-49.

[14] Silva, V. M. D., Torres Filho, R. D. A., \& Resende, J. V. D. (2017). Rheological properties of selected Brazilian honeys as a function of temperature and soluble solid concentration. International journal of food properties, 20(sup3): S2481-S2494.

[15] Apriani, D., Gusnedi, G., \& Darvina, Y. (2013). Studi tentang nilai viskositas madu hutan dari 
beberapa daerah di sumatera barat untuk mengetahui kualitas madu. Pillar of Physics, 2(1): 91-98.

[16] Kamila, R., Syarief, R., \& Saptono, I. T. (2017). Analisis pengembangan bisnis madu pada CV Ath-Thoifah dengan pendekatan business model canvas. Jurnal Agribisnis Indonesia, 5(2): 173184.

[17] Sarah, D., Suryana, R. N., \& Kirbrandoko, K. (2019). Strategi Bersaing Industri Madu (Studi Kasus: CV Madu Apiari Mutiara). Jurnal Aplikasi Bisnis dan Manajemen (JABM), 5(1): 71-83.

[18] Swari, N. I., Wirawan, R., Qomariyah, N., \& Al Hadi, K. (2019). Analisis Kadar Air Dalam Madu Menggunakan Kombinasi Metode Kapasitansi Dan Indeks Bias. KONSTAN-JURNAL FISIKA DAN PENDIDIKAN FISIKA, 4(1): 1-10.

[19] Bouhlali, E. D. T., Bammou, M., Sellam, K., El Midaoui, A., Bourkhis, B., Ennassir, J., ... \& FilaliZegzouti, Y. (2019). Physicochemical properties of eleven monofloral honey samples produced in Morocco. Arab Journal of Basic and Applied Sciences, 26(1): 476-487.

[20] Marcazzan, G. L., Mucignat-Caretta, C., Marina Marchese, C., \& Piana, M. L. (2018). A review of methods for honey sensory analysis. Journal of Apicultural Research, 57(1): 75-87.

[21] Saefatu, S. S. S., \& Setiawan, A. (2012). Menguji kemurnian madu melalui pengukuran viskositas zat cair. In Prosiding Seminar Nasional Sains dan Pendidikan Sains UKSW.

[22] Kek, S. P., Chin, N. L., Yusof, Y. A., Tan, S. W., \& Chua, L. S. (2017). Classification of entomological origin of honey based on its physicochemical and antioxidant properties. International journal of food properties, 20(sup3): S2723-S2738.

[23] Dinkov, D. (2003). A scientific note on the specific optical rotation of three honey types from Bulgaria. Apidologie, 34(3): 319-320.

[24] Primorac, L., Flanjak, I., \& Topolnjak, Z. (2011). Specific rotation and carbohydrate profile of Croatian unifloral honeys. Czech Journal of Food Sciences, 29(5): 515-519.

[25] Bertoncelj, J., Golob, T., Kropf, U., \& Korošec, M. (2011). Characterisation of Slovenian honeys on the basis of sensory and physicochemical analysis with a chemometric approach. International journal of food science \& technology, 46(8): 1661-1671.

[26] Chakir, A., Romane, A., Marcazzan, G. L., \& Ferrazzi, P. (2016). Physicochemical properties of some honeys produced from different plants in Morocco. Arabian Journal of Chemistry, 9: S946S954.

[27] Oroian, M. (2013). Measurement, prediction and correlation of density, viscosity, surface tension and ultrasonic velocity of different honey types at different temperatures. Journal of Food Engineering, 119(1): 167-172.

[28] de Almeida-Muradian, L. B., Stramm, K. M., \& Estevinho, L. M. (2014). Efficiency of the FT-IR ATR spectrometry for the prediction of the physicochemical characteristics of M elipona subnitida honey and study of the temperature's effect on those properties. International journal of food science \& technology, 49(1): 188-195.

[29] Yap, S. K., Chin, N. L., Yusof, Y. A., \& Chong, K. Y. (2019). Quality characteristics of dehydrated raw Kelulut honey. International Journal of Food Properties, 22(1): 556-571.

[30] Machado De-Melo, A. A., Almeida-Muradian, L. B. D., Sancho, M. T., \& Pascual-Maté, A. (2018). Composition and properties of Apis mellifera honey: A review. Journal of Apicultural Research, 57(1): 5-37.

[31] Alvarez-Suarez, J. M., Gasparrini, M., Forbes-Hernández, T. Y., Mazzoni, L., \& Giampieri, F. (2014). The composition and biological activity of honey: a focus on Manuka honey. Foods, 3(3): 420-432.

[32] Manyi-Loh, C. E., Ndip, R. N., \& Clarke, A. M. (2011). Volatile compounds in honey: a review on their involvement in aroma, botanical origin determination and potential biomedical activities. International Journal of Molecular Sciences, 12(12): 9514-9532.

[33] Costa, P. A., Moraes, I. C. F., Bittante, A. M. Q., do Amaral Sobral, P. J., Gomide, C. A., \& Carrer, C. C. (2013). Physical properties of honeys produced in the Northeast of Brazil. International Journal of Food Studies, 2(1): 118-125.

[34] Gleiter, R. A., Horn, H., \& Isengard, H. D. (2006). Influence of type and state of crystallisation on the water activity of honey. Food Chemistry, 96(3): 441-445.

[35] Shamsudin, S., Selamat, J., Sanny, M., Abd. Razak, S. B., Jambari, N. N., Mian, Z., \& Khatib, A. (2019). Influence of origins and bee species on physicochemical, antioxidant properties and botanical discrimination of stingless bee honey. International Journal of Food Properties, 22(1): 
Viscosity of Sumbawa Honey Based on Faxen Correction Factor: Consumer Protection Efforts against Fraud Moh. Irma Sukarelawan, Yudhiakto Pramudya, Siti Anisatur Rofiqah, Endra Putra Raharja

239-264.

[36] Belay, A., Haki, G. D., Birringer, M., Borck, H., Lee, Y. C., Cho, C. W., ... \& Melaku, S. (2017). Sugar profile and physicochemical properties of Ethiopian monofloral honey. International Journal of Food Properties, 20(11): 2855-2866.

[37] Abdulkhaliq, A., \& Swaileh, K. M. (2017). Physico-chemical properties of multi-floral honey from the West Bank, Palestine. International Journal of Food Properties, 20(2): 447-454.

[38] Mossel, B., Bhandari, B., D'Arcy, B., \& Caffin, N. (2003). Determination of viscosity of some Australian honeys based on composition. International Journal of Food Properties, 6(1): 87-97.

[39] James, O. O., Mesubi, M. A., Usman, L. A., Yeye, S. O., Ajanaku, K. O., Ogunniran, K. O., ... \& Siyanbola, T. O. (2009). Physical characterisation of some honey samples from North-Central Nigeria. International Journal of Physical Sciences, 4(9): 464-470.

[40] Lewoyehu, M., \& Amare, M. (2019). Comparative evaluation of analytical methods for determining the antioxidant activities of honey: A review. Cogent Food \& Agriculture, 5(1): 1685059.

[41] Thrasyvoulou, A., Tananaki, C., Goras, G., Karazafiris, E., Dimou, M., Liolios, V., ... \& Gounari, S. (2018). Legislation of honey criteria and standards. Journal of Apicultural Research, 57(1): 8896.

[42] Boussaid, A., Chouaibi, M., Rezig, L., Missaoui, R., Donsí, F., Ferrari, G., \& Hamdi, S. (2015). Physicochemical, rheological, and thermal properties of six types of honey from various floral origins in Tunisia. International journal of food properties, 18(12): 2624-2637.

[43] Kraftmakher, Y. (2010). Rotational viscometers - a subject for student projects. Physics Education, 45(6): 622-628.

[44] Li, W., Kagan, G., Hopson, R., \& Williard, P. G. (2011). Measurement of Solution Viscosity via Diffusion-Ordered NMR Spectroscopy (DOSY). Journal of Chemical Education, 88(9): 13311335.

[45] Mulyono, T., Putra, A. S., \& Neran, N. (2013). Disain Viskometer Kapiler Terkomputerisasi (The Design of Computerized Capillary Viscometer). Jurnal Sains dan Teknologi Kimia, 4(2): 169-173.

[46] Nelkon, M., \& Parker, P. (1995). Advanced Level Physics, 3rd ed. London: Heinemann Educational Books.

[47] Oktova, R., \& Diana, N. (2013). Penentuan koefisien viskositas air menggunakan metode getaran pegas dengan koreksi kedalaman penetrasi dan koreksi efek dinding. Berkala Fisika Indonesia, 5(1): 25-34.

[48] Pascual-Maté, A., Osés, S. M., Fernandez-Muino, M. A., \& Sancho, M. T. (2018). Methods of analysis of honey. Journal of Apicultural Research, 57(1): 38-74.

[49] Landau, L. D., \& Lifshitz, E. M. (1987). Fluid Mechanics, 2nd ed. Oxford: Pergamon.

[50] Viswanath, D. S., Ghosh, T. K., Prasad, D. H. L., Dutt, N. V. K., \& Rani, K. Y. (2007). Viscosity of Liquids: Theory, Estimation, Experiment, and Data. Netherlands: Springer.

[51] Pain, H. J. (2005). The Physics of Vibrations and Waves, 6th ed. London: John Wiley \& Sons ltd.

[52] Zaitoun, S., Ghzawi, A. A. M., Al-Malah, K. I., \& Abu-Jdayil, B. (2001). Rheological properties of selected light colored Jordanian honey. International Journal of Food Properties, 4(1): 139-148.

[53] Saxena, S., Panicker, L., \& Gautam, S. (2014). Rheology of Indian honey: Effect of temperature and gamma radiation. International journal of food science, 2014: 1-6.

[54] Mossel, B., Bhandari, B., D'Arcy, B., \& Caffin, N. (2000). Use of an Arrhenius model to predict rheological behaviour in some Australian honeys. LWT-Food Science and Technology, 33(8): 545552. 